\title{
Penelitian
}

\section{PENGARUH PEMBERIAN EKSTRAK ETANOL RIMPANG LENGKUAS (ALPINIA GALANGA) TERHADAP GAMBARAN HISTOPATOLOGI HEPAR MENCIT (MUS MUSCULUS L.) YANG DIINDUKSI MONOSODIUM GLUTAMATE}

\author{
Theodora Agverianti ${ }^{1}$, Muhartono ${ }^{2}$, Khairun Nisa \\ Berawi $^{3}$ \\ ${ }^{1}$ Fakultas Kedokteran, Universitas Lampung, Lampung \\ ${ }^{2}$ Departemen Patologi Anatomi, Fakultas Kedokteran, \\ Universitas Lampung, Lampung \\ ${ }^{3}$ Departemen Fisiologi, Fakultas Kedokteran, Universitas \\ Lampung, Lampung
}

\begin{abstract}
ABSTRAK
Latar Belakang: Konsumsi Monosodium Glutamate (MSG) secara berlebihan dan jangka waktu lama dilaporkan memicu kerusakan hepar. Dampak toksik pada hepar yaitu degenerasi, nekrosis hepatosit, dan peningkatan peroksidasi lipid. Antioksidan pada rimpang lengkuas diharapkan dapat memperbaiki derajat kerusakan hepar akibat radikal bebas pada MSG. Metode: Penelitian ini adalah penelitian eksperimental dengan rancangan Post Test Only Control Group Design. Sampel dalam penelitian ini adalah mencit berjumlah 25 ekor yang dibagi dalam 5 kelompok, yaitu kontrol negatif (tidak diberikan perlakuan), kontrol positif (diberikan MSG $4 \mathrm{mg} / \mathrm{gBB}$ selama 14 hari), perlakuan 1 (diberikan MSG 4 mg/gBB selama 14 hari dilanjutkan ekstrak etanol rimpang lengkuas $14 \mathrm{mg} / 20 \mathrm{gBB}$ selama 7 hari), perlakuan 2 (diberikan MSG $4 \mathrm{mg} / \mathrm{gBB}$ selama 14 hari dilanjutkan ekstrak etanol rimpang lengkuas $28 \mathrm{mg} / 20 \mathrm{gBB}$ selama 7 hari), dan perlakuan 3 (diberikan MSG $4 \mathrm{mg} / \mathrm{gBB}$ selama 14 hari dilanjutkan ekstrak etanol rimpang lengkuas $56 \mathrm{mg} / 20 \mathrm{gBB}$ selama 7 hari). Kemudian dilakukan pembedahan untuk pemeriksaan histopatologi. Hasil: Dari hasil rerata skoring didapatkan perhitungan degenerasi sel hepar kontrol positif $(11,8)$, kontrol negatif $(5,2)$, perlakuan $1(10,6)$, perlakuan $2(8,4)$, dan perlakuan $3(7,6)$. Berdasarkan hasil uji One Way ANOVA, diperoleh nilai $p=0,001$ terhadap gambaran histopatologi hepar mencit. Kesimpulan: Terdapat pengaruh pemberian ekstrak etanol rimpang lengkuas terhadap gambaran histopatologi hepar yang diinduksi MSG
\end{abstract}

Kata Kunci: Hepar, Histopatologi, Monosodium Glutamate, Lengkuas

\section{ABSTRACT}

Background: Long term consumption of Monosodium Glutamate (MSG) in excess is reported induced liver damage. Toxic effect in liver are due to the degeneration and necrosis of hepatocytes, which also increases lipid peroxidation. Antioxidant in galangal rhizome is expected to repair liver damage caused by free radicals in MSG. Method: This study is an experimental research with Post Test Only Control Group Design. The samples in this study are 25 mice divided into 5 groups which are, negative control (not given any treatment), positive control (given MSG $4 \mathrm{mg} / \mathrm{gBW}$ for 14 days), treatment 1 (given MSG 4 $\mathrm{mg} / \mathrm{gBW}$ for 14 days continued with ethanol extract of galangal rhizome $14 \mathrm{mg} / 20 \mathrm{gBW}$ for 7 days), treatment 2 (given MSG $4 \mathrm{mg} / \mathrm{gBW}$ for 14 days continued with ethanol extract of 
galangal rhizome $28 \mathrm{mg} / 20 \mathrm{gBW}$ for 7 days), and treatment 3 (given MSG $4 \mathrm{mg} / \mathrm{gBW}$ for 14 days continued with ethanol extract of galangal rhizome $56 \mathrm{mg} / 20 \mathrm{gBW}$ for 7 days). Then surgery was needed for histopathological examination. Results: Based on mean scoring results, the results showed calculation of liver cell degeneration for positive control $(11,8)$, negative control $(5,2)$, treatment $1(10,6)$, treatment $2(8,4)$, and treatment $3(7,6)$. Based on the test results One Way ANOVA, the result showed the value of $p=0,001$ for liver histopathological appearance of mice. Conclusion: There is an effect of ethanol extract of galangal rhizome to the liver histopathological appearance of male mice.

\section{Keywords: Alpinia galanga, Hepar, Histopathology, Monosodium Glutamate}

\section{PENDAHULUAN}

Hepar merupakan organ pusat metabolisme dalam tubuh. Hepar merupakan organ yang amat rentan karena merupakan filter dari bahan-bahan toksik yang masuk ke dalam tubuh. ${ }^{1}$ Salah satu penyebab tersering kerusakan hepar adalah karena efek toksik. Kandungan toksik yang umumnya ditemui adalah radikal bebas. Radikal bebas dalam jumlah besar dapat menyebabkan kerusakan hepar, salah satu sumber radikal bebas adalah zat penyedap tambahan makanan. ${ }^{2}$

Salah satu penyedap yang umum digunakan adalah Monosodium Glutamate (MSG). ${ }^{3}$ World Health Organization (WHO) dan Food and Agriculture Organization (FAO) menetapkan MSG sebagai bahan penyedap yang aman, akan tetapi ditemui banyak laporan mengenai efek konsumsi MSG. ${ }^{4}$

Penelitian yang dilakukan dengan pemberian MSG pada tikus dewasa dengan dosis $16 \mathrm{~g} / \mathrm{kgBB}$ selama 14 hari berturut-turut menyebabkan terhambatnya perkembangan sel-sel hepar. Adapun pemberian dengan dosis $32 \mathrm{~g} / \mathrm{kgBB}$ selama 14 hari berturut-turut menyebabkan eritrosit lisis, dilatasi vena sentral, kerusakan hepatosit akut, nekrosis dan atropi. ${ }^{5}$ Pemberian MSG secara intraperitoneal dosis $4 \mathrm{mg} / \mathrm{gBB}$ mencit selama 15 hari menunjukkan adanya degenerasi sel hepar akibat stres oksidatif. ${ }^{6}$ MSG sebagai zat radikal bebas dapat memicu degenerasi struktur molekul lemak yang menyusun hepar. Peroksidasi lipid menjadi ekstensif dan mengganggu fluiditas membran dan mengganggu fungsi makromolekul. ${ }^{7}$

Berbagai usaha dilakukan agar dapat mempertahankan tubuh dari efek toksik radikal bebas, salah satunya dengan pemberian antioksidan. Kandungan antioksidan utama yang terkandung pada rimpang lengkuas adalah flavonoid. Ekstrak lengkuas mampu menghambat enzim cyclooxygenase serta menurunkan volume dan berat granuloma pada inflamasi dan berperan sebagai agen antiinflamasi pada mencit yang mengalami stres oksidatif. ${ }^{8}$

\section{METODE}

Penelitian ini dilakukan bulan November-Desember $2017 \quad$ di Laboratorium Fisiologi, Biokimia, dan Biomolekuler dan Laboratorium Anatomi, Histologi, dan Patologi Anatomi Fakultas Kedokteran Universitas Lampung dengan menggunakan desain penelitian Post Test Only Control Group Design. Sampel penelitian yang digunakan adalah 25 ekor mencit (Mus musculus L.) yang dibagi menjadi kelompok kontrol negatif, kelompok kontrol positif, dan kelompok perlakuan. Kelompok kontrol negatif tidak diberikan perlakuan apapun selama 21 hari, kontrol positif diberikan $4 \mathrm{mg} / \mathrm{gBB}$ MSG selama 14 hari, perlakuan 1 diberikan 4 mg/gBB MSG selama 14 hari dilanjutkan dengan ekstrak etanol rimpang lengkuas dosis $14 \mathrm{mg} / 20 \mathrm{gBB}$ selama 7 hari, perlakuan 2 diberikan 4 $\mathrm{mg} / \mathrm{gBB}$ MSG selama 14 hari dilanjutkan dengan ekstrak etanol rimpang lengkuas dosis $28 \mathrm{mg} / 20 \mathrm{gBB}$ selama 7 hari, dan perlakuan 3 diberikan $4 \mathrm{mg} / \mathrm{gBB}$ MSG selama 14 hari dilanjutkan dengan ekstrak etanol rimpang lengkuas dosis $56 \mathrm{mg} / 20$ gBB selama 7 hari. Monosodium Glutamate (MSG) dilarutkan dalam 0,5ml aquades dan diberikan secara intraperitoneal, sementara ekstrak etanol rimpang lengkuas diberikan secara peroral. Pada hari ke-22 dilakukan pembedahan untuk selanjutnya dilakukan 
penilaian gambaran histopatologi hepar mencit (Mus musculus L.).

Preparat diamati di bawah mikroskop dengan perbesaran 400x pada lima lapang pandang. Kriteria penilaian histopatologi yang diamati sesuai dengan model skoring histopatologi Manja Roegnik yaitu, degenerasi parenkimatosa, degenerasi hidropik, dan nekrosis.

Data yang diperoleh akan diolah menggunakan SPSS 24.00 for Windows lalu dilakukan uji Shapiro Wilk untuk melihat normalitas data. Setelah data terdistribusi normal, dilanjutkan dengan uji One Way ANOVA untuk melihat perbedaan rerata kelompok kontrol dan kelompok perlakuan lalu dilanjutkan dengan uji Post Hoc untuk melihat perbedaan kelompok.

\section{HASIL PENELITIAN}

Pada hasil pengamatan terlihat degenerasi sel hepar terbanyak terdapat pada kelompok kontrol $(+)$ yang hanya diberikan MSG 4 mg/gBB saja selama 14 hari, selanjutnya terlihat penurunan perhitungan degenerasi sel hepar seiring meningkatnya dosis ekstrak etanol rimpang lengkuas pada kelompok perlakuan 1, 2, dan 3. Angka degenerasi sel hepar terkecil didapatkan pada kelompok kontrol (-) yang tidak diberikan perlakuan apapun. Grafik hasil perhitungan degenerasi sel dapat terlihat pada gambar 1 .

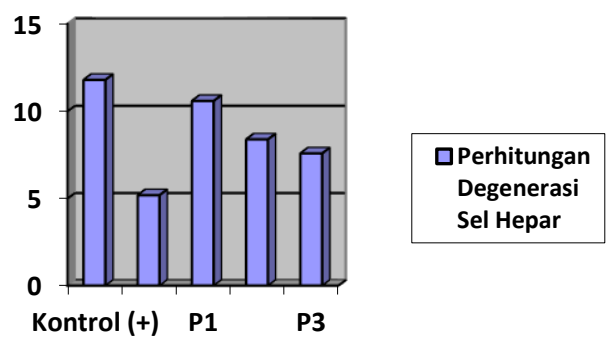

\section{Gambar 1. Hasil Perhitungan Degenerasi Sel Hepar}

Pada hasil gambaran histopatologi degenerasi sel hepar setelah pemberian MSG $4 \mathrm{mg} / \mathrm{gBB}$ dan ekstrak etanol rimpang lengkuas dosis $14 \mathrm{mg} / 20 \mathrm{gBB}, 28$ $\mathrm{mg} / 20 \mathrm{gBB}$, dan $56 \mathrm{mg} / 20 \mathrm{gBB}$ terlihat adanya degenerasi parenkimatosa dan degenerasi hidropik seperti terlihat pada Gambar 2.

Perhitungan degenerasi sel hepar mencit (Mus musculus L.) diuji dengan One Way ANOVA untuk mengetahui efek pemberian MSG serta pemberian ekstrak etanol rimpang lengkuas. Hasil yang didapatkan adalah $p=0,001(p<0,05)$ yang berarti terdapat perbedaan degenerasi sel hepar bermakna pada lebih dari 2 kelompok percobaan. Setelah dilakukan pengamatan pada penelitian yang telah dilakukan didapatkan penurunan degenerasi sel hepar yang bermakna terhadap jumlah dosis ekstrak etanol rimpang lengkuas yang diberikan. Pada uji One Way ANOVA didapatkan $\mathrm{p}<0,05$, sehingga data bermakna secara statistik dan dilanjutkan dengan uji Post Hoc. Pada uji Post Hoc terlihat adanya pengaruh perlakuan terhadap penurunan degenerasi sel hepar yang bermakna secara statistik terhadap peningkatan dosis ekstrak etanol rimpang lengkuas pada kontrol negatif dan kontrol positif, kontrol negatif dan $\mathrm{P} 1$, kontrol negatif dan P2, kontrol negatif dan P3, kontrol positif dan $\mathrm{P} 2$, kontrol positif dan $\mathrm{P} 3, \mathrm{P} 1$ dan $\mathrm{P} 2$, P1 dan P3. Didapatkan pula hasil tidak bermakna secara statistik $(p>0,05)$ pada kontrol positif dengan P1, P2, dan P3. 

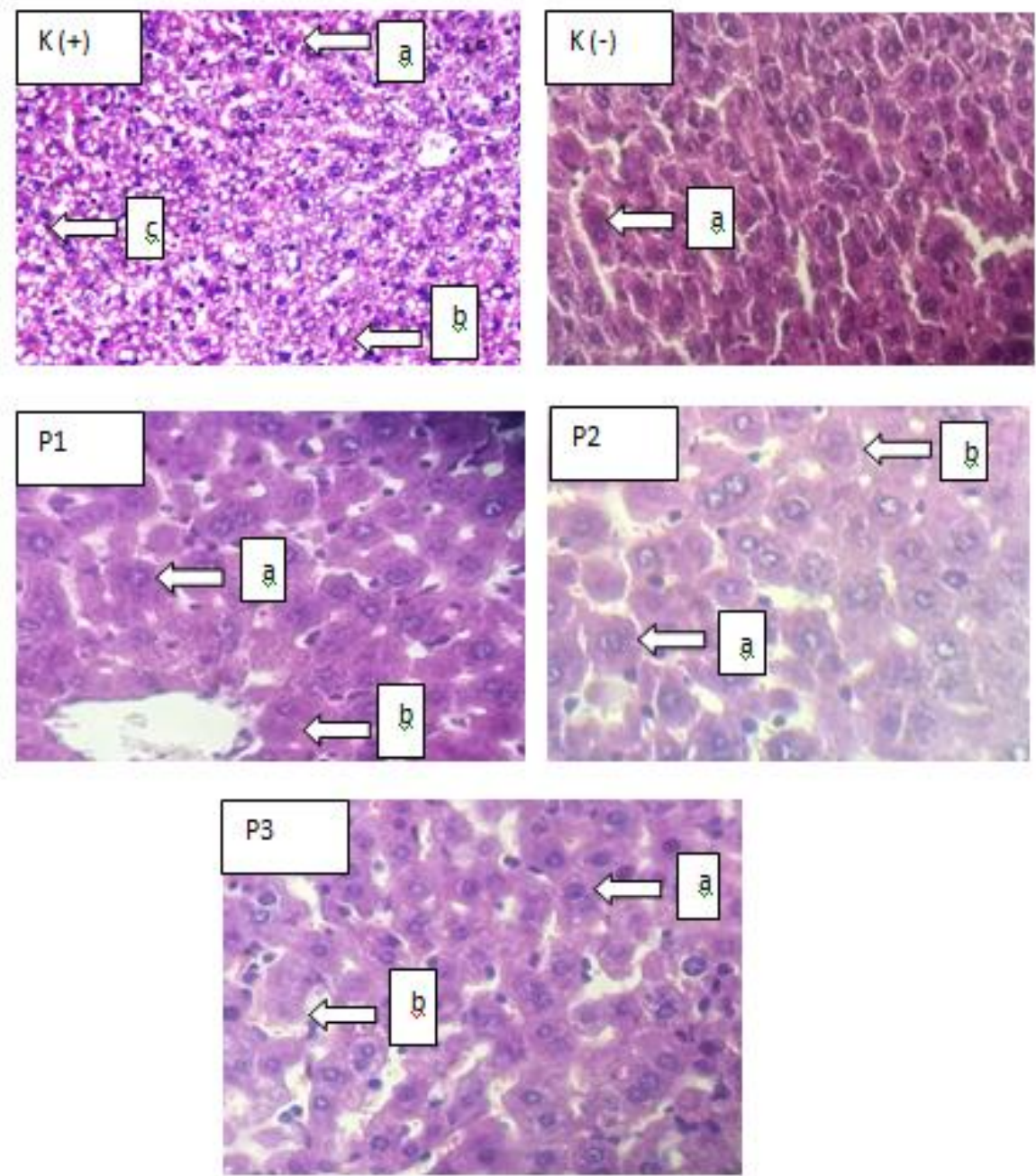

Gambar 2. Histopatologi Hepar Mencit

Keterangan: a: Sel hepatosit normal; b: Degenerasi parenkimatosa; c: Degenerasi hidropik 


\section{PEMBAHASAN}

Monosodium Glutamate (MSG) digunakan oleh masyarakat sebagai penambah cita rasa pada makanan. Pemberian MSG selama 14 hari dapat menghambat perkembangan sel hepar. ${ }^{5}$ Terlihat pula adanya degenerasi sel hepar dengan pemberian secara intraperitoneal dosis MSG $4 \mathrm{mg} / \mathrm{gBB}$ mencit selama 15 hari. ${ }^{6}$ Kandungan glutamate pada MSG dapat memicu stres oksidatif yang menyebabkan peroksidasi lipid. Peroksidasi lipid menyebabkan kerusakan membran sel lalu mengakibatkan kerusakan baik pada struktur maupun fungsi sel. ${ }^{7}$

Pada sel hepar yang mengalami kerusakan maka dapat terlihat perubahan struktur sel hepar seperti degenerasi dan nekrosis. Perubahan degeneratif adalah perubahan bersifat reversibel sehingga jika stimulan yang menyebabkan kerusakan dihentikan pajanannya maka sel dapat kembali sehat seperti sebelum distimulasi, sedangkan nekrosis merupakan perubahan bersifat irreversibel sehingga tidak dapat kembali seperti semula walaupun pajanan stimulan dihentikan dan sel telah mencapai titik akhir kerusakan sehingga berakibat pada kematian sel. ${ }^{9}$

Degenerasi merupakan proses awal pada kerusakan sel hepar. Degenerasi mengakibatkan sel mengalami pembengkakan. Hal tersebut terlihat pada kelompok dengan pemberian MSG. Pemberian MSG menyebabkan cairan intrasel masuk ke sitosol dalam jumlah besar. Hal ini dapat lebih mudah terjadi pada membran sel yang terganggu permeabilitasnya. Perubahan sifat membran dari unsurunsur sel seperti mitokondria dan lisosom dapat terjadi akibat peroksidasi lipid karena induksi radikal bebas secara terus-menerus. Efek toksik mulanya akan merusak membran sel, selanjutnya akan merusak bagian inti sehingga mengakibatkan struktur dan fungsi tidak normal dan lama-kelamaan akan mengakibatkan terjadinya nekrosis. ${ }^{10}$

$$
\text { Pada hasil pengamatan }
$$

didapatkan terjadi perubahan struktur berupa degenerasi parenkimatosa dan degenerasi hidropik pada semua kelompok kecuali kelompok kontrol negatif yang tidak diberikan perlakuan apapun. Degenerasi parenkimatosa merupakan perubahan yang ditandai dengan pembengkakan sel disertai sitoplasma yang bergranula akibat endapan protein sehingga jaringan tampak keruh. Pembengkakan sel terjadi pada mitokondria dan retikulum endoplasma. Degenerasi ini memiliki sifat reversibel. ${ }^{11}$

Degenerasi hidropik dapat pula ditemui di semua kelompok dengan induksi MSG. Degenerasi hidropik memiliki tingkat kerusakan lebih berat dibandingkan degenerasi parenkimatosa. Degenerasi hidropik memiliki sebab yang dianggap sama dengan degenerasi parenkimatosa, hanya intensitasnya lebih, jangka waktunya lebih lama, dan tempat terjadinya pembengkakan tidak hanya di mitokondria dan retikulum endoplasma saja. Pada degenerasi hidropik terlihat gambaran pembengkakan sel, air mengumpul dalam rongga-rongga sel, dan vakuola kecil bersatu membentuk vakuola lebih besar sehingga inti sel terdesak ke pinggir. ${ }^{9}$

Perubahan-perubahan ini dapat dikaitkan dengan penelitian sebelumnya yaitu pemberian MSG subkutan pada mencit sebanyak $2 \mathrm{mg} / \mathrm{gBB}$ selama 75 hari memperlihatkan adanya degradasi dan hipertrofi hepatosit, gangguan struktur vena, dan munculnya sel inflamasi di antara vena sentral disertai dengan adanya nucleus berbagai ukuran di hepatosit. ${ }^{2}$ Selain itu, MSG dapat memicu perdarahan lokal hepar dan piknosis nucleus yang ditandai dengan larutnya kromosom dan proses kondensasi pada nukleus. ${ }^{12}$ Terlihat pula adanya peningkatan enzim penanda fungsi hepar Alanine aminotransferase (ALT) dan y glutamyle transferase (GGT) akibat stres oksidatif yang dipicu MSG. ${ }^{13}$

Salah satu langkah menurunkan efek buruk radikal bebas adalah konsumsi antioksidan. Kandungan antikosidan yang umumnya telah dikenal adalah flavonoid. ${ }^{14} \quad$ Flavonoid dapat digunakan untuk melawan efek buruk radikal bebas dari MSG. Flavonoid banyak terkandung pada tumbuhan. Salah satunya pada rimpang lengkuas yang memiliki kandungan flavonoid 
berupa galangin, kaemferol, dan kuersetin dengan efek antioksidan yang sangat baik..$^{15}$ Selain itu, pada bagian rimpang lengkuas terdapat dua senyawa fitokimia, yaitu Acetoxy Chavicol Acetate (ACA) dan Hydroxy Chavicol Acetate (HCA) yang memiliki efek antitumor, antiinflamasi, antimikroba, dan antioksidan. ${ }^{16}$ Kandungan ACA pada ekstrak lengkuas dapat menghambat proses inflamasi dengan menghambat Nitric Oxide (NO) dan Cyclooxygenase 2 (COX-2) sehingga mencegah kerusakan sel. Acetoxy Chavicol Acetate juga dapat meningkatkan apoptosis melalui aktivasi caspase-3 dan metabolisme polyamine, sehingga memiliki potensi sebagai zat antikanker. ${ }^{17}$ Dari hasil penelitian terlihat bahwa dosis ektrak etanol rimpang lengkuas memberi pengaruh penurunan perhitungan degenerasi sel hepar. Dosis paling tinggi pada penelitian ini memberi hasil yang paling baik dibandingkan dengan kelompok perlakuan lainnya. Adapun dosis tertinggi yang mempunyai efek paling baik adalah $56 \mathrm{mg} / 20 \mathrm{gBB}$.

Penurunan degenerasi sel hepar yang bermakna terhadap peningkatan dosis ekstrak etanol rimpang lengkuas yang diberikan dapat terjadi akibat pengaruh kandungan flavonoid pada rimpang lengkuas sebagai antioksidan yang dapat menangani dampak buruk radikal bebas akibat induksi MSG. Antioksidan dapat mengurangi dampak buruk radikal bebas dalam tubuh dengan menstabilkan radikal bebas melalui cara melengkapi elektron yang kurang pada radikal bebas, menghambat reaksi berantai dan pembentukan radikal bebas yang dapat menimbulkan stres oksidatif dan kerusakan sel hepar. ${ }^{18}$

Pada hasil pengamatan didapatkan ekstrak etanol rimpang lengkuas dosis $28 \mathrm{mg} / 20 \mathrm{gBB}$ dan 56 $\mathrm{mg} / 20 \mathrm{gBB}$ memiliki hasil secara statistik bermakna terhadap perhitungan degenerasi sel hepar, sedangkan dosis $14 \mathrm{mg} / 20 \mathrm{gBB}$ secara statistik tidak bermakna. Hal ini dapat terjadi karena antioksidan yang terkandung dalam dosis $14 \mathrm{mg} / 20 \mathrm{gBB}$ belum dapat menangani kerusakan yang diakibatkan oleh radikal bebas pada MSG secara efektif. Seperti diketahui berdasarkan hasil konversi, didapatkan dosis efektif ekstrak etanol rimpang lengkuas adalah
$28 \mathrm{mg} / 20 \mathrm{gBB}$, sehingga dapat disimpulkan dosis lebih kecil dari dosis efektif akan mengakibatkan kurang efektifnya kerja antioksidan. Hal ini berkaitan dengan penelitian sebelumnya yang menyebutkan pemberian antioksidan dosis bertingkat dapat menurunkan jumlah degenerasi sel hepar dan menghentikan penyebaran radikal bebas. ${ }^{4}$

Pada penelitian ini, peneliti juga menghadapi keterbatasan yaitu, penelitian ini hanya melihat struktur histopatologi saja sehingga tidak menjelaskan perubahan fungsi pada organ hepar mencit (Mus musculus L.) dan metode pengenceran MSG yang masih sederhana sehingga kesesuaian perhitungan dosis tidak dapat dilakukan secara presisi.

\section{SIMPULAN}

Terdapat pengaruh pemberian ekstrak etanol rimpang lengkuas terhadap gambaran histopatologi hepar mencit (Mus musculus L.) yang diinduksi MSG.

\section{SARAN}

Pada penelitian selanjutnya diperlukan penelitian untuk melihat perubahan fungsi hepar mencit (Mus musculus L.) yang diinduksi MSG serta penggunaan alat ukur yang lebih teliti untuk penentuan dosis pengenceran MSG yang lebih presisi.

\section{DAFTAR PUSTAKA}

1. Muliartha IKG, Endang S, Yuliawati. Pemberian Kombinasi Vitamin $C$ dan $E$ Peroral Memperbaiki Kerusakan Hepar Akibat Paparan Rokok Kretek Subkronik. Jurnal Kedokteran Brawijaya. 2009;25(1):23-7.

2. Bhattacharya T, Bhakta A, Ghosh SK. Long Term Effect of Monosodium Glutamate in Liver of Albino Mice After Neo-natal Exposure. Nepal Med Coll J. 2011;13(1):11-16.

3. Suci EN. Histologi Hasil Ulas Vagina dan Waktu Siklus Estrus Mencit (Mus musculus, L.) Setelah Pemberian Monosodium Glutamat (MSG). Skripsi. Kendari: Universitas Halu Oleo. 2015. 
4. Maulida A, Syafruddin I, Salomo H. Pengaruh Pemberian Vitamin $C$ dan E terhadap Gambaran Histologis Hepar Mencit (Mus musculus L.) yang Dipajankan Monosodium Glutamat (MSG). Repository USU. 2013;1(2):15-20.

5. Eweka AO, Om'iniabosh F. Histological Studies of the Effects of Monosodium Glutamate on the Small Intestine of Adult Wistar Rats. Journal of Gastroenterology. 2008;2(1):14-8.

6. Kanti EAA, Susianti. Pengaruh Pemberian Vitamin C terhadap Gambaran Histologis Hepar Mencit Jantan Dewasa (Mus musculus) yang Diinduksi Monosodium Glutamate. Juke Unila. 2012;81-95.

7. Reiter RJ. Oxidative Process and Antioxidative Defense Mechanism in the Aging Brain. FASEB Journal. 2005;9(1):526-33.

8. Baldo DEB, Serrano JE. Screening for Intestinal Anti-inflammatory Activity of Alpinia galangal Against Acetic acid-Induced Colitis in Mice (Mus musculus). Journal of Medicinal Plants Studies. 2016;1(4):72-7.

9. Price S, Lorraine M. Patofisiologi: Konsep Klinis Proses-proses Penyakit. Jakarta: EGC, 2004.

10. Haryatmi. Kemampuan Vitamin $E$ sebagai Antioksidan terhadap Radikal Bebas pada Lanjut Usia. Tesis. Semarang: FKIP UMS. 2004.

11. Bhara MLA. Pengaruh Pemberian Kopi Dosis Bertingkat per Oral 30 hari terhadap Gambaran Histologis Hepar Tikus Wistar. Tesis. Semarang: Universitas Diponegoro. 2009.

12. Khumbare V, Gajbe U, Singh BR, Reddy AK, Shukla S. Histological \&
Histochemical Changes in Liver of Adult Rats Treated with Monosodium Glutamate: A Light Microscopic Study. World Journal of Pharmacy and Pharmaceutical Sciences. 2015:4(4):898-911.

13. Tawfik MS, Al-Badr N. Adverse Effects of Monosodium Glutamate on Liver and Kidney Functions in Adult Rats and Potential Protective Effect of Vitamin $C$ and $E$. Scientific Research. 2012:3(1):651-9.

14. Mahae N, Siree C. Antioxidant Activities and Antioxidative Components in Extract of Alpinia galanga (L.) Sw. Nat.Sci. 2009;43(1):358-69.

15. Wathoni N, Rusdiana T, Hutagaol RY. Formulasi Gel Antioksidan Ekstrak Rimpang Lengkuas (Alpinia galanga L.Willd) dengan Menggunakan Basis Aqupec 505 HV. Farmaka. 2009;7(1):15-27.

16. Samarghandian S, Afshari JT, Davoodi S. Honey Induces Apoptosis in Renal Cell Carcinoma. Pharmacogn Mag. 2014;7(25):4652.

17. Hartono, NWB. Pengaruh Alpinia galanga (Lengkuas) terhadap Aktivitas Proliferasi Sel dan Indeks Apoptosis pada Adenokarsinoma Mamma Mencit C3H. Tesis. Semarang: Universitas Diponegoro. 2009.

18. Schram DD, Karim M, Schrader HR, Holt RR, Cardetti M, Keen CL. Honey with High Levels of Antioxidants Can Provide Protection to Healthy Human Subjects. Journal of Agricultural and Food Chemistry. 2003;51(6):1732-5. 